\title{
Climate change, development, poverty and economics
}

\section{Samuel Fankhauser and Nicholas Stern}

October 2016

Centre for Climate Change Economics and Policy Working Paper No. 284

Grantham Research Institute on Climate Change and the Environment Working Paper No. 253 
The Centre for Climate Change Economics and Policy (CCCEP) was established by the University of Leeds and the London School of Economics and Political Science in 2008 to advance public and private action on climate change through innovative, rigorous research. The Centre is funded by the UK Economic and Social Research Council. Its second phase started in 2013 and there are five integrated research themes:

1. Understanding green growth and climate-compatible development

2. Advancing climate finance and investment

3. Evaluating the performance of climate policies

4. Managing climate risks and uncertainties and strengthening climate services

5. Enabling rapid transitions in mitigation and adaptation

More information about the Centre for Climate Change Economics and Policy can be found at: http://www.cccep.ac.uk.

The Grantham Research Institute on Climate Change and the Environment was established by the London School of Economics and Political Science in 2008 to bring together international expertise on economics, finance, geography, the environment, international development and political economy to create a world-leading centre for policy-relevant research and training. The Institute is funded by the Grantham Foundation for the Protection of the Environment and the Global Green Growth Institute. It has nine research programmes:

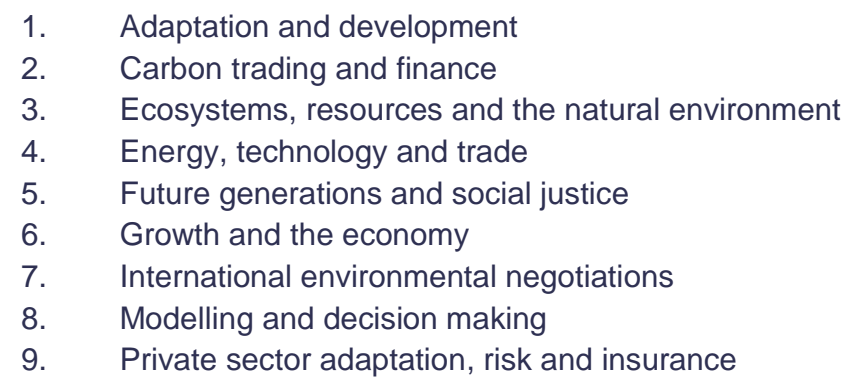

More information about the Grantham Research Institute on Climate Change and the Environment can be found at: http://www.lse.ac.uk/grantham.

This working paper is intended to stimulate discussion within the research community and among users of research, and its content may have been submitted for publication in academic journals. It has been reviewed by at least one internal referee before publication. The views expressed in this paper represent those of the author(s) and do not necessarily represent those of the host institutions or funders. 


\section{Climate Change, Development, Poverty and Economics}

Samuel Fankhauser ${ }^{\mathrm{a}}$ and Nicholas Stern ${ }^{\mathrm{ab}}$

17 October 2016

Acknowledgements: This paper is forthcoming as a chapter in K. Basu, D. Rosenblatt and C. Sepulveda, eds. The State of Economics, the State of the World, Cambridge, MA: MIT Press. We would like to thank Gael Girard, Mike Toman, Bob Ward and the participants of the World Bank conference on The State of Economics, the State of the World (Washington DC, June 2016) for their thoughtful comments. Patrick Curran and Isabella Neuweg have provided outstanding research support. We also acknowledge financial support from the Grantham Foundation for the Protection of the Environment and the UK Economic and Social Research Council (ESRC), through its support of the Centre for Climate Change Economics and Policy (CCCEP).

${ }^{\text {a }}$ Grantham Research Institute on Climate Change and the Environment and Centre for Climate Change Economics and Policy (CCCEP), London School of Economics and Political Science.

${ }^{\mathrm{b}}$ IG Patel Professor of Economics and Government, London School of Economics and Political Science and President of the British Academy. 


\section{Introduction}

The past three decades have seen an unprecedented increase in world living standards and a fall in poverty across many fundamental dimensions. Increased confidence in what was possible together with greater acceptance of moral responsibilities led to the adoption of the Millennium Development Goals (MDGs) at the turn of the century. They provided a real basis for international cooperation and development. In the Sustainable Development Goals (SDGs), agreed in September 2015, there is now a common platform for the next phase of the fight against poverty.

The SDGs make it clear that environmental protection will be a key feature of this next phase and increasingly intertwined with poverty reduction. Thirteen of the 17 SDGs are directly concerned with the natural environment, climate or sustainability. Environment, climate and sustainability were not prominent in the MDGs. With hindsight we can now see that this was a mistake.

A key factor in all this is climate change. Climate change is not the only environmental problem we face, nor is it the only threat to global prosperity. But climate change is unique in its magnitude and the vast risks it poses. It is a potent threat-multiplier for other urgent concerns, such as habitat loss, disease and global security (IPCC 2014) and puts at risk the development achievements of the past decades (World Bank 2016). If unchecked, climate change could fundamentally redraw the map of the planet, and where and how humans and other species can live.

Climate change is also unique in the scale of the response that is needed. Reducing climate risks requires cooperation from all countries, developed and developing, to reorient their economic systems away from fossil fuels and harmful land-use practices. This reorientation is urgent. Our activities in the next two decades will determine whether our successes in development will be sustained or advanced, or whether they will be undermined or reversed in a hostile environment.

The nature of the climate problem has implications for economic analysis. Economics has much to offer, and indeed continues to provide important insights, but there has been a dangerous tendency to force climate change into narrow existing ways of thinking. This must change. We need to construct theories and models that reflect the structure and scale of the problem and the contexts in which it occurs.

Climate change also has implications for development policy. In the Paris Agreement negotiated at the end of 2015 - there is now an international platform through which global climate action can be advanced and coordinated. The Paris Agreement sets out a process through which the rise in global mean temperatures may be curtailed to "well below" $2^{\circ} \mathrm{C}$ above preindustrial levels and perhaps as low as $1.5^{\circ} \mathrm{C}$. These are the central long-term objectives of the agreement.

Meeting the Paris objectives requires sustained action over many decades. It also requires the reorientation of investment. At least US\$ 100 trillion will be invested over the next two or three 
decades into buildings and urban infrastructure, roads, railways, ports and into new energy systems. It is imperative that these investment decisions are taken with climate change in mind. If they are there will be substantial benefits for development and poverty reduction - living spaces where we can move, breathe and be productive, better protection for fragile ecosystems, as well as the fundamental reduction of the risks of climate change.

Putting the SDGs and Paris together, the agreements of 2015 have given us, for the first time, a global agenda for sustainable development applying to all countries. This paper sets out the implications of this agenda, and climate change in particular, for development economics and development policy. It emphasizes the nature of the required changes and their implications. We start with an examination of what economics has had to say about the link between economic prosperity and the environment. We then explain why climate change is a different kind of problem and why it requires a new approach to both analysis and policy. The final two sections explore how this new approach might look.

\section{Prosperity and the environment}

Environmental concerns entered development policy relatively late. The World Bank created the Office of the Environmental Advisor in 1970, but in the early years this was very much an advisory function. Over time the role evolved and the environment grew in importance, culminating in the creation of the Environmentally Sustainable Development Vice Presidency in 1993. ${ }^{1}$ In parallel, environmental economics began to emerge as a new field of academic study (Pearce 2002).

Understanding the interactions between economic growth and environmental protection is crucial to development in all countries, but especially in poor ones. Careful environmental management is a critical ingredient of any viable path to poverty reduction. Bad environmental management results in environmental degradation, poor health and lost economic output. Poor people are the primary victims of these trends, though we should recognize that poverty also contributes to them (Pearce and Warford 1993).

\section{Environment and growth}

Knowledge about the link between economic development and the environment goes of course back much further than the 1970s. The economics pioneers of the $18^{\text {th }}$ and $19^{\text {th }}$ century were well aware of environmental resources as an essential source of wealth, and indeed as a potential constraint to economic growth. For David Ricardo differences in land quality were the main source of rent for land owners. Thomas Malthus, more pessimistically, predicted widespread poverty as a consequence of population growth and decreasing returns in agriculture. The early focus was on resource endowments. Climatic factors rarely featured. Montesquieu speculated at length about the influence of the climate on society and the "temper of the mind" (Montesquieu 1748, Book XIV), but the link to economic performance was cursory.

\footnotetext{
${ }^{1}$ https://archivesholdings.worldbank.org/
} 
Unlike Montesquieu's theories on the climate, Malthus' concern about natural resource constraints has remained a constant feature of the growth debate. In the 1860s William Stanley Jevons worried about the future of industrial England when its coal reserves would run out. In the 1970s the Club of Rome made headlines with The Limits to Growth (Meadows et al. 1972). Inspired by Kenneth Boulding's (1966) notion of "spaceship Earth", the interdisciplinary field of ecological economics has continued to probe the natural boundaries, which the laws of science impose on economic processes (e.g., Rockström et al. 2009).

So far, Malthus and the resource pessimists have generally appeared to be wrong. Human ingenuity has mostly managed to outpace natural resource constraints. This does not mean environmental resources are not overexploited. They are, including not least in developing countries. However, in most cases this appears, in large measure, to be the result of policy mismanagement and market failure, rather than resource scarcity per se.

\section{The management of natural resources}

From the outset, economists have devoted considerable attention to the effective management of natural resources. In the $19^{\text {th }}$ century Knut Wicksell and Martin Faustmann were among the first to study the optimal harvesting cycle for slow-maturing resources like forests (Hedlund-Nyström et al. 2006). However, it was Harold Hotelling (1931) who produced the defining treatise on natural resource management. According to his Hotelling rule, the value of natural resources, if optimally used, must rise at the rate of interest. This insight has formed the basis of natural resource economics to this day. It also informs the analysis of stock pollution problems like climate change.

The Hotelling rule was revisited in the 1970s, when it became apparent that it may not be consistent with an emerging development concept, that of sustainable development. The notion of sustainable development was popularized by the Brundtland Commission on Environment and Development, which defined it as "development which meets the needs of current generations without compromising the ability of future generations to meet their own needs" (Brundtland et al. 1987).

For economists, this meant consumption (or utility) could not be allowed to decrease over time. Robert Solow and John Hartwick worked out what non-decreasing utility meant for resource depletion. The rents from natural resource extraction had to be re-invested into other forms of capital, so that the total stock of environmental, physical and human capital remained constant (Solow 1974, Hartwick 1977). The World Bank has been at the forefront of translating the Hartwick-Solow rule into practical policy advice (World Bank 2011).

\section{Environmental management and public policy}

If Harold Hotelling is the forefather of natural resource economics, Arthur Cecil Pigou deserves the credit for incorporating environmental concerns into welfare economics. Drawing on his teacher Alfred Marshall, Pigou introduced systematically into economics the notion of 
externalities, that is, costs or benefits that are not captured in the market price of goods. Later writers added nuance and extensions - such as open access problems, common property resources and public goods - that refine our understanding of environment-related market failures, but the core concept of externalities remains central to modern environmental economics.

Pigou's observations on the environment were prescient. He discussed at length the negative effects of pollution, which "inflicts a heavy uncharged loss on the community" (Pigou 1920, as cited in Sandmo 2015). The concern remains valid to this day. Urban air pollution, linked to particulate matter and other pollutants, remains a major issue in most countries (New Climate Economy 2014). In another perceptive comment, Pigou praised the external value of forests, whose "beneficial effect on climate often extends beyond the borders of the estates owned by the person responsible for the forest", though he probably had the local climate in mind (ibid).

Pigou also identified the requisite remedy to address these market failures: a corrective tax levied in proportion to the externality. This was later complemented by the work of Ronald Coase, who showed that problems of externalities could also be managed via clearer (and perhaps tradable) property rights (Coase 1960). Both writers were drawing on John Stuart Mill, who already in 1848 had called for government intervention to ensure the "common enjoyment" of the world's natural riches (Sandmo 2015). Today, variants of Pigovian taxes and Coasean trading schemes are in use throughout the world (for an overview, see Sterner 2003; Freeman and Kolstad 2007).

Following in Pigou's footsteps, John Hicks and Nicholas Kaldor developed the theory for a systematic comparison of the costs and benefits of policy intervention. James Meade (1955) provided the defining general equilibrium approach and analysis in his seminal book Trade and Welfare (see also Drèze and Stern 1987, 1990). Cost-benefit analysis soon became the standard tool for project appraisal, including in development organizations like the World Bank (e.g., Little and Mirrlees 1974).

In environmental economics, the extensive body of work on welfare economics gave rise to the field of environmental valuation - the use of techniques that monetize the external value of the environment, so it can be appropriately reflected in cost-benefit analysis (for an overview, see Hanley and Barbier 2009).

It soon became clear that nature's contribution to human welfare goes well beyond the provision of food and materials, which had exercised Malthus and the Club of Rome. The modern theory of ecosystem services (e.g., TEEB 2010) distinguishes between provisioning services (food, water, materials), cultural services (spiritual value, recreation, mental and physical health), regulating services (air quality, water treatment, carbon sequestration) and support services (genetic diversity, habitats). The full extent of this rich range of services is not yet fully understood or indeed always appreciated by policy makers. It remains an active and important area of interdisciplinary research. 
A central test for any economic prescriptions on environmental management is the health of the natural environment. Against this yardstick the economics of Hotelling, Pigou, Meade and their successors has serious limitations. There have been notable successes, but on the whole environmental protection in practice has been much harder than the solutions embodied in simple theory. The political economy of poverty and the environment is particularly complex and has to include factors like power, exclusion, land rights, market access and gender relations.

Unfortunately, the environment - development nexus has become more complex still. The environmental problems of the $21^{\text {st }}$ century could be of a different order of magnitude and generality than those of the past, and none more so than climate change.

\section{Why climate change is different}

Climate change is different from past environmental problems in terms of its scale, the magnitude of risks and the urgency of action. We are all involved both in the generation of the problems and in our vulnerability to its impacts. Climate change is also different in terms of its complexity and the difficulty of identifying a "solution". To appreciate the nature and scale of the challenge it is necessary to set out some basic science about climate change.

\section{Science}

The science around climate change is based on almost two centuries of theory and evidence. The basic physics of the greenhouse effect - that there are heat-trapping gases in the atmosphere, which lead to the Earth to retaining heat - were established by Jean-Baptiste Fourier and John Tyndall in the second half of the $19^{\text {th }}$ century. Studying the Earth's heat balance, the former showed that something was preventing the escape of energy, and the latter identified the key gases at work. At the start of the $20^{\text {th }}$ century Svante Arrhenius made the link to fossil fuel-based emissions by showing that they intensified the magnitude of the natural greenhouse effect. In the first half of the $20^{\text {th }}$ century, with the rise of quantum theory, it was established that the mechanism at work was the frequency of oscillation of greenhouse gases, which interfered with that of infrared energy. The systematic monitoring of atmospheric $\mathrm{CO}_{2}$ concentrations began in 1958.

This part of the physics and chemistry of the atmosphere is basic and clear. Important uncertainties remain, but we increasingly understand the main driving forces within the inherently complex and chaotic system that is the Earth's climate. From all this evidence, which continues to be gathered, published and presented, we understand that the current, unprecedented climate change starts and ends with people.

Human activity, through the extraction and combustion of fossil fuels, removal of forests, or agricultural activities contributes to the emissions (or "flow") of greenhouse gases. The increased flows lead to increased quantities (or "stocks") of greenhouse gases in the atmosphere and with it an increase in the amount of heat energy trapped by the atmosphere. As the heat energy increases, 
so to does the average global land and sea temperature. With higher temperatures and more energy there is increased intensity and variability within the global climate system, leading to fluctuations or changes in local and regional weather patterns.

\section{Risks}

The implications of this complex causal chain are difficult to comprehend in their entirety and the specifics cannot be predicted with certainty. However, it is clear that the effects in terms of human lives and livelihoods are potentially severe.

Since the beginnings of the Industrial Revolution in the mid-1800s the atmospheric concentration of the main greenhouse gases has increased from around 285 parts per million (ppm) of carbon dioxide equivalent $\left(\mathrm{CO}_{2} \mathrm{e}\right)$ to over $450 \mathrm{ppm}$ of $\mathrm{CO}_{2} \mathrm{e}$ today, of which $400 \mathrm{ppm}$ is $\mathrm{CO}_{2}$. Around 70 years ago we were adding approximately $0.5 \mathrm{ppm}$ of $\mathrm{CO}_{2} \mathrm{e}$ per year and now we are adding around $2.5 \mathrm{ppm}$ of $\mathrm{CO}_{2} \mathrm{e}$ per year. If this trend continues the median temperature increase over the next one or two centuries would be in the region of $4^{\circ} \mathrm{C}$, with a substantial probability of well over $4^{\circ} \mathrm{C}$ (IPCC, 2013).

To put these numbers into context, our civilization has developed during the climatically benign Holocene period, following the last ice-age which came to an end around 9,000 or 10,000 years ago. The Holocene has had relatively stable temperatures that fluctuated in a range of $\pm 1^{\circ} \mathrm{C}$ to $1.5^{\circ} \mathrm{C}$ relative to the late $19^{\text {th }}$ century benchmark. We are now near the edge of that range, with global temperatures across the Earth's surface of around $1^{\circ} \mathrm{C}$ above the long-term average (Met Office, 2016). If the temperature increase reaches $3^{\circ} \mathrm{C}$ or $4^{\circ} \mathrm{C}$ we would be outside the range of experience of our species, Homo Sapiens, which is around 250,000 years old. The planet has not seen $3^{\circ} \mathrm{C}$ for around 3 million years (when the sea level was around 20 meters higher than today, IPCC 2013), and $4^{\circ} \mathrm{C}$ for tens of millions of years.

Along with the physical science, the natural and social sciences are rapidly developing and investigating the risks of rising temperatures for economies, ecosystems, cultures, movement and social structures. The specifics cannot be known with certainty, but the World Bank (2012) anticipates a significant risk of "unprecedented heat waves, severe drought, and major floods in many regions, with serious impacts on human systems, ecosystems, and associated services", exacerbating and compounding other threats like habitat loss, stability and disease (IPCC 2014).

Poor countries and poor people would be hit particularly hard. They rely more heavily on climate sensitive economic activities like agriculture and have weaker capacity to adapt effectively. Poor people are also more likely to live in hazard zones, such as flood plains, and their assets are more likely to be damaged in extreme weather events. They are also more susceptible to the pests and diseases that follow heat waves, floods and drought (World Bank 2016).

The risks will increase as temperatures rise and we breach potential environmental tipping points, such as the thawing of the permafrost and associated release of methane. These tipping points (or abrupt shifts) are more likely for temperature increases above $2-3^{\circ} \mathrm{C}$, but some are forecast to 
occur within the $1.5^{\circ} \mathrm{C}$ to $2^{\circ} \mathrm{C}$ range set in the Paris Agreement (Drijfhout et al, 2015). Even $2^{\circ} \mathrm{C}$ should not therefore be seen as a "safe" limit. It is degrees of danger at stake, particularly those of tipping points and irreversible outcomes.

\section{The urgency}

Limiting temperature rises to any level requires the restriction of the accumulation of long-lived greenhouse gases in the atmosphere. The concentration of greenhouse gases in the atmosphere cannot exceed a certain threshold and must stabilize at a lower level. The lower the temperature target, the lower the threshold and stabilization level and the sooner emissions will have to peak. Eventually, global annual emissions will have to reach "net-zero", that is, there is a balance between the release of greenhouse gases into the atmosphere from human activities and their removal (for example through reforestation).

The $2^{\circ} \mathrm{C}$ upper temperature bound in the rise in global mean surface temperature is often associated with a threshold atmospheric concentration of no more than $450 \mathrm{ppm} \mathrm{CO}_{2} \mathrm{e}$ for all greenhouse gases in 2100 . This would mean limiting the annual emissions of carbon dioxide, the most important greenhouse gas, to a budget of maybe $600-1100 \mathrm{GtCO}_{2}$ over the period to 2100 . This would give us a 50 per cent chance of restricting the rise in global mean surface temperatures to $1.5-1.7^{\circ} \mathrm{C}$ by 2100 (IPCC, 2014). The probability of remaining below $2^{\circ} \mathrm{C}$ by 2100 would be 66 percent. More favorable probabilities would require a tighter $\mathrm{CO}_{2}$ budget.

To remain within an emissions budget of $600-1100 \mathrm{GtCO}_{2}$ global emissions would have to peak before 2020 and decline rapidly from then on. Negative emissions technology (e.g. bioenergy combined with carbon capture and storage) may be required later in the century to avoid warming of more than $2^{\circ} \mathrm{C}$.

The global emissions budget creates a zero-sum game. The higher are one country's emissions the lower will have to be those of others. It is here that disagreements occur. Developed countries are responsible for the majority of historical greenhouse gas emissions. But the balance of annual emissions has shifted in recent years. Developing countries (led by China) now account for around 60 per cent of total annual emissions and will be responsible for most future emissions growth (New Climate Economy, 2014). Six of the top 10 emitters are developing countries (WRI, 2014).

\section{Cooperation}

Tackling climate change thus requires efforts from all countries and strong international cooperation. Experience tells us that such cooperation can be hard to secure. International cooperation on climate change has historically been difficult.

The benefits that accrue from reduced climate risks are a global public good. Countries cannot be excluded from profiting and have incentives to free-ride if they perceive reducing emissions to be costly to themselves and disregard the benefits to others. Moreover, the group that would benefit 
is large and diverse and the impacts of accelerated climate change affect countries unevenly. These are strong reasons why reaching an agreement is difficult, but they are also the reasons why international cooperation is needed (Barrett 2003).

Against this backdrop, the Paris Agreement is a remarkable breakthrough in international climate cooperation. To illustrate this, compare Paris to another agreement that seemed almost impossible at the time. The Bretton Woods Agreement brought together 44 countries, in an attempt to rebuild the international economic and financial system in a more cooperative form. Keynes (1944, cited in Braithwaite and Drahos, 2001, p.98) described it as "forty-four nations ... actually able to work together at a constructive task in amity and unbroken concord. Few believed it possible. If we can continue in a larger task as we have begun in this limited task, there is hope for the world."

While the Bretton Woods agreement should be regarded as a crucial achievement, it is important to recognize the urge for collaboration in the post-war era and the call for international coordination were almost omnipresent. The grave experience of two world wars and a great depression in 30 years taught some clear and strong lessons. The consequences of the failure to work together were demonstrated to be catastrophic; the evidence was hard and real. Further, the USA was in a dominant position. In contrast, the Paris Agreement brings together over 170 countries in anticipation of future harm, which makes it all the more remarkable. And no one country was dominant.

That an agreement was formed lies not only in the increased understanding of the gravity of the risks but also, and crucially, in an understanding of the attractiveness of alternative pathways towards sustainable development. This has changed the calculus of self-interested action. But the agreement also includes features that enhance the willingness to cooperate, by increasing the benefits of cooperation and realizing them more quickly, such as international collaboration on low-carbon research and development (Keohane and Victor, forthcoming). Moreover, transfers between country coalitions (in the form of funds, commitments etc.) helped make the agreement more profitable to participants. However, we should also not under-estimate a shared sense of responsibility. Much of the motivation appeared to be beyond narrow self-interest and was about responsibility to future generations.

Yet, however remarkable, the deal struck in Paris must be seen as only the beginning of a long process of international cooperation. The effectiveness of the agreement is yet to be tested. The building blocks that have led to the agreement will need to be expanded and deepened. The pledges submitted ahead of Paris, if fully implemented, still put the world on an emissions path that is closer to $3^{\circ} \mathrm{C}$ warming than the Paris objective of "well below" $2^{\circ} \mathrm{C}$ (UNEP 2015). Without even closer cooperation by and action from all countries over the next 10 to 15 years the chance of remaining well below $2^{\circ} \mathrm{C}$ is slim. 


\section{The analytical challenge: beyond the marginalist approach}

Economists were slow to recognize the enormity of climate change and its relevance to economic development. Climate change has yet to reach the mainstream in many economics departments. Yet a small number of pioneers have engaged with the topic from an early stage(Nordhaus 1982; 1991a, b; Edmonds and Reilly 1983; Cline 1992; Manne and Richels 1992; Schelling 1992).

The authors of those early papers applied the tools of their trade. The groundbreaking work of William Nordhaus and the integrated assessment models it gave rise to were inspired by the growth theory of Ramsey and Solow. The accumulation of greenhouse gases in the atmosphere was understood as an exhaustible resource problem in the spirit of Hotelling. The likely impacts of climate change were enumerated, monetized and aggregated in the tradition of Pigou and Meade. To correct the externality, economists advocated Pigovian carbon taxes or Coasean emissions trading schemes (see Fankhauser 1995 for an overview of early climate economics).

Their contributions were essential in building the argument for action. However, by placing a strong focus on the marginalist tools of welfare economics, economists have tended to underestimate both the potential impacts of climate change and the wider benefits of a transition to low-carbon growth, to the point where their models were increasingly at odds with the science. They have focused on fairly marginal perturbations to long-term growth when the question at hand is the management of immense risk and the longer term. Growth itself could be severely disrupted and reversed and not simply perturbed on the margin.

\section{The precautionary economics of climate change risks}

Initial estimates of the economic costs of climate change began to emerge in the 1990s. They were both derived from and provided input into integrated assessment models (IAMs). These models attempt to combine the key elements of biophysical and economic systems and represent the full cycle from socio-economic activity to emissions, temperature change and impacts that then feed back into the socio-economics. It was a valiant endeavor, but the early models suffered from a poor evidence base. Many important impacts either had to be omitted or were extrapolated from single data points (Tol and Fankhauser 1998). This had the effect of marginalizing or ignoring some of the most worrying risks associated with the science.

Today, our evidence base is much better (IPCC 2014). More solid empirical evidence is beginning to emerge on the impacts of moderate climate change, for example as regards agricultural impacts (e.g., Schlenker et al. 2005; Schlenker and Lobell 2010) and labor productivity (e.g., Burke et al 2015; Heal and Park 2013). There is also case study evidence on the link between climate and conflict (Kelley et al., 2015; Hsiang and Burke 2014).

However, there are inherent limits to the empirical investigation of severe climate impacts on people. The nature of the problem is precisely that it will take us outside the range of the empirically observed in the history of Homo Sapiens (see above). To understand the 
consequences of the large temperature changes we might face we have to go back longer in time and study the evidence from paleo-climatology, for example on sea levels.

The IPCC therefore concluded that the results of IAMs depend on a number of "disputable" assumptions (IPCC 2014). This is hard to disagree with when, in one common specification, a temperature increase of $5^{\circ} \mathrm{C}$ is associated with damages equivalent to just 5-10 per cent of GDP. Temperatures at that level have not been seen for tens of millions of years. The transformation would likely be traumatic.

IAMs still have a role to play. However, their value does not lie in producing specific estimates of economic damage, which can be profoundly misleading. It lies in documenting the high levels of risk we face. Multiple model runs and some understanding of the omitted impacts show that the balance of uncertainty is heavily tilted toward the downside. Negative surprises relative to the effects that are incorporated are much more likely than positive ones. Economic tools can be used to translate these uncertainties into prescriptions for risk management.

An important strand of research, pioneered by Martin Weitzman, is demonstrating the importance of looking not just at the most likely outcomes, but also at the tail of the distribution (Weitzman 2012). However, while the focus on the tails is welcome, the central estimates of potential change over the long term - beyond past human experience - are themselves deeply worrying and offer sufficient grounds for strong action (Stern 2016).

\section{The dynamic economics of a low-carbon transition}

The economic models available to study low-carbon development paths often, in the structure and approach, predate the debate on climate change and have their origin in energy sector planning. At the core of many models are estimates of marginal abatement costs (MAC), that is, the incremental cost of reducing emissions by an additional tonne. MAC-based models have been useful in informing the low-carbon strategies of many countries. However, by focusing on emission reduction efforts at the margin, they often ignore the inherently systemic nature and dynamic force of transformative change.

Some system-wide effects will make carbon abatement more expensive than would be the case in their absence. We should not underestimate the difficulty of deep structural change. One key concern is rigidities in the labor market both in terms of labor mobility and wages (Bowen and Kuralbayeva 2015). There are also rigidities in the capital stock. Carbon-intensive capital is often long-lived and assets might get stranded unless investment decisions are sufficiently forwardlooking (Pfeiffer et al. 2016). Finally there is inertia associated with innovation, which appears to be heavily path-dependent (Aghion et al. 2016). Few of these effects are properly modelled as yet, but they point to the dangers of locking in high-carbon capital and infrastructure.

On the other hand there are potentially very large gains from future innovation around cheaper and sustainable paths. There is potential to harness the large dynamic benefits of low-carbon innovation - unlocking the process of "creative destruction" which Joseph Schumpeter described 
back in the 1940s. This includes not just technological innovation but also changes in business practices and social behavior (Stern 2016). As engineers learn how to install, connect and repair technology cheaply, unit costs fall faster for many new technologies than for existing ones. Also influential will be the emergence of new networks, such as the integration of electric-vehicleenergy storage into smart grids. Dechezleprêtre et al. (2014) find that clean technology innovation creates much higher spillovers than conventional innovation, on a par with those in transformative sectors like IT and nanotechnology. New technologies and wise management and investment can both produce very large gains in energy efficiency. Indeed nearly half of the required action on climate change could come from energy efficiency.

The low-carbon transition also has other environmental benefits from reduced fossil-fuel pollution (air and water) to the preservation of the world's forests. In China and India, probably close to two million people die each year as a result of poor air quality (New Climate Economy 2014). These are environmental priorities of immense significance that could and should be pursued in their own right, but the low-carbon transition offers opportunities for synergies and coordination.

\section{The ethics of intervention}

The magnitude of climate risks and the lasting impact of policy choices on lives and livelihoods, both today and in the future, raise issues of equity and justice that are more severe and more difficult than we usually encounter in policy analysis.

There are different ethical approaches to guide the actions of individuals and communities, but they all provide consistent normative support for strong action (Stern, 2007, 2015). Moral guidance is also offered in the teachings of major religions. Concern around future generations, deep respect for the environment and the duties of the current generation as stewards of the earth are consistent themes. ${ }^{2}$

The ethics discourse in economics has, for the most part, made little accommodation or room for these wider philosophical, ethical and religious perspectives. It has focused heavily on technical issues, unusually narrowly defined, in particular the intergenerational question of discounting and the intra-generational issue of burden sharing, or dividing up the remaining carbon space.

Discounting is of course a central issue and requires rigorous, analytical scrutiny from economic, philosophical and political perspectives. It is discussed in great detail elsewhere and readers are referred to Stern $(2007,2014,2015)$. Those papers argue strongly against pure time-discounting because it is essentially "discrimination by date of birth" that would be unacceptable, for example, in criminal courts, voting and human rights. If it were to be introduced as an ethical criteria it would require direct and convincing argument: such argument is usually conspicuous by its absence.

\footnotetext{
2 This can be seen from the Papal encyclical Laudato Si: On Care for Our Common Home, the Islamic Declaration on Global Climate Change, the Bhumi Devi Ki Jai! (A Hindu Declaration on Climate Change), and the Buddhist Climate Change Statement to World Leaders.
} 
These papers also point out that speaking of "the discount rate" as if it was something introduced entirely from outside is a serious conceptual mistake. The discount factor is a relative price between goods now and in the future. It depends on which goods and which dates. It is a relative price logically prior to the concept of the discount rate which is the rate of fall of the discount factor. Discount factors, and thus, discount rates, like other prices and values, depend on where we turn out to be and that depends on our decisions. They are endogenous to our decisionmaking.

The ethics of "burden sharing", too, are often misconstrued. There is a powerful argument that developed countries have a moral obligation, from their history, their wealth and their technology, to take a strong lead in cutting emissions. However, the current arguments tend to see rights and allocations only in terms of a single dimension, greenhouse gas emissions. The focus on this one dimension ignores a multitude of other relevant influencing factors and the dynamics and co-benefits of the alternative low-carbon transition.

There are no permanent links that suggest greenhouse gas emissions are needed for development. They may be necessary in the early stages of transformation but not indefinitely. While energy is a basic requirement for development it does not necessarily, at least in a technical sense, have to be associated with greenhouse gas emissions, since it is possible to source energy with low or zero emissions. It can be argued that each country or individual has a right to development, a right to energy and a right to basic human needs, but they neither separately nor together imply a right to emit or degrade the environment.

\section{The policy challenge: beyond incremental action}

The development community is increasingly aware of the risks of climate change (e.g., World Bank 2010, 2012, 2016). However, it has yet to respond to the threat with sufficient purpose and scale. Climate policy is not about incremental initiatives that can be attached to existing development plans. It requires deep structural and systemic change, implemented over many decades, both to reduce emissions and adapt to remaining climate risks.

\section{Climate-resilient development}

It is well recognized that even moderate amounts of climate change can pose risks to development. What is less appreciated is the extent to which the rapid development that many developing countries are undergoing, for example along urban coastlines (Hanson et al. 2011), is shaping their future vulnerability to climate change.

The pace of development means that the greatest opportunities for achieving climate resilience lie in influencing these trends. Policy makers should incorporate climate risks into long-term development, infrastructure and spatial planning decisions. This macro-level approach is an important departure from traditional analysis, which has tended to treat adaptation to climate change as a set of self-standing, threat-specific responses, such as coastal protection schemes. 
How does climate-resilient development differ from conventional development? Thomas Schelling, one of the first economists to engage with climate change, famously claimed that economic development was the best form of adaptation, implying that conventional and climateresilient development are one and the same (Schelling 1992, 1997).

Climate resilience and economic progress are indeed heavily intertwined. However, not all forms of development have the same effect on climate resilience. As countries develop the structure of their economy evolves, typically away from agriculture. Sectors become more productive and the location of economic activity may shift to urban centers. Income per capita rises, and with higher incomes the demand for climate protection goes up.

Of these changes, only the increased demand for adaptation unequivocally reduces climate change risks. The net effect of the other trends is unclear. Although agriculture is highly sensitive to climate change, a structural shift into industry and urban living improves resilience only if those sectors and locations are subject to less climate risks than agriculture, which they may not be (Fankhauser and McDermott 2014, 2016). For example, much urban development has involved building on flood plains.

Pursuing climate-resilient development at the macro scale has institutional consequences. The responsibility for adaptation shifts from environment departments and hydro-meteorological offices to planning and economic ministries. These tend to be more powerful and better able to instigate the necessary reforms. It is an important and sometimes overlooked side-effect of moving from project-level adaptation to climate-resilient development.

In integrating development and climate action, we should recognize that development (conventionally understood), mitigation and adaptation are closely intertwined. For example, low-till and SRI approaches in agriculture save energy and water, reduce emissions/less soil distribution and methane release via flooded rice fields), and are more resilient. There are many further examples in energy and buildings.

\section{The low-carbon transition}

Fossil fuel-based energy has been such a powerful force of growth and poverty reduction that it seems reasonable to ask, in the words of Dercon (2012), whether "green growth is good for the poor". It is a long standing concern. The original text of the UN Framework Convention on Climate Change deals extensively with the question of "who bears the incremental costs", implying that there is a "horse race" between growth and environmental responsibility.

We now know that the notion of a "horse race" represents a false dichotomy. We have highlighted above the dynamic benefits of an innovation-driven growth model, where learning processes and economies of scale create investment and employment opportunities. We have also outlined the environmental benefits of such a course of action, for example in terms of air quality, and the great scope to improve resource efficiency. We have emphasized the intertwining of development, mitigation and adaptation. 
The challenge for development policy is to guide economic decisions in this new direction. Even if it is beneficial, structural transformation is never easy. Policy makers will have to tackle fundamental market failures not just in relation to greenhouse gases, but also in networks, capital markets, clean innovation, the provision of information and with respect to the local, regional and global environment. There are harmful policy distortions, not least the subsidization of fossil fuels and the underpricing of energy, which amount to hundreds of billions of dollars each year (OECD 2015; Coady et al 2015). The vested interests can be very powerful. Political skills and systems will be tested severely.

The choice of policies will be important. Carbon pricing has proven an effective tool to incentivize emission reductions with very limited effects, so far, on competitiveness (Dechezleprêtre and Sato 2014). The break-through of low-carbon technology requires additional support for clean research and early deployment (Dechezleprêtre et al 2016). Thoughtful regulation (and its enforcement) also has a role to play, for example in the form of efficiency standards, planning rules and building codes. Another essential part of the policy mix is strategies to reduce structural adjustment costs, by supporting labor mobility, providing social safety nets and protecting low-income households.

Spurring low-carbon growth requires the redirection of financial flows and investment. Private investors will only do this if the balance of risks and returns is attractive and the direction of travel is clear. The consistency, clarity and credibility of climate policies therefore matter hugely. This is not something current political processes always deliver. Government-induced policy risk is an immense disincentive across the world. However, it is possible to reduce policy uncertainty, for example through statutory carbon targets, enshrined in legislation and monitored by an independent non-political body (Fankhauser 2013).

A key concern is infrastructure. Over the next 20 years the required investment in infrastructure will be in the region of US\$ 100 trillion or more (Bhattacharya et al, 2015). This new capital will be long-lasting and the choices made now will have enduring consequences for growth, development and the climate. Currently around 60 per cent of global annual greenhouse gas emissions can be attributed to the investment in and use of infrastructure. The very rapid urbanization (likely to rise from around 3.5 billion people now to around 6.5 billion people by mid-century) demonstrates the immense dangers of lock-in of wasteful and polluting structures. These numbers show that the investment of the next 20 years will shape the future profoundly: whether we have cities where we can move and breathe and whether we can hold the global temperature rise to $2^{\circ} \mathrm{C}$. Sadly, the criticality of the next two decades and the urgency of action are all too poorly understood.

\section{Conclusions}

Human ingenuity has succeeded in overcoming natural resource constraints that were once thought binding. That extraordinary progress has not been sufficient to eradicate global poverty, and the natural environment has suffered, but human welfare has improved markedly. However, 
the environment and development challenges of the $21^{\text {st }}$ century are likely to be more difficult than those of the past.

Nowhere is this more evident than for climate change. Climate change is a threat of a completely different magnitude and character from those of the past. To continue our progress in the face of climate risks we need both strong policy action and a radical deepening of economic analysis. We need to construct theories and models that reflect the unique challenges we now face and the contexts in which they arise.

The response to the threat is not the cessation of economic growth (Jackson 2011, Klein 2015). It is possible to advance economic prosperity and combat climate change at the same time. We argue that an approach to growth driven by clean innovation and investment can create new growth and employment opportunities. The economic, structural and technological challenges of sustainable growth are massive, but the opportunities are real and very attractive.

However, time is short. Over the next two decades the emerging markets of Asia, Africa and Latin America will build their cities, infrastructure and energy systems. Developed nations will need a major renewal of theirs. The way we take these decisions will determine whether we have a chance of keeping climate change below $2^{\circ} \mathrm{C}$.

There is some reason for optimism. In the Paris Agreement (December 2015) and the Sustainable Development Goals (September 2015) the international community now has a platform through which climate change, environment and development can be integrated into planning, financing and investment decisions. We have a global agenda for the first time in which all countries are involved.

To guide these decisions we call for a radical deepening of economic analysis. Climate change is the biggest and most important example of systemic global risk but it is not the only one and we, in economics, have to learn to think about and investigate these issues much more carefully. Standard growth theory, general equilibrium and marginal methods will, as ever, have much to contribute but they will not be sufficient. We should seek a dynamic economics where we tackle directly issues involving pace and scale of change in the context of major and systemic risks.

We also call for a departure from development business as usual. Poor countries have a large pent-up demand for modern forms of energy, transport and essential consumption goods that must now be met in a low-carbon way. They will suffer most from the adverse effects of climate change and need a form of economic development that manages their climate exposure and increases their capacity to adapt. A key focus must be investment in sustainable infrastructure. The world needs strong and clear policies to foster those investments and a major expansion in finance to undertake them. The development banks with their range of instruments, the confidence arising from their presence and the ability to take a long-term view have a vital role to play. 
Managing climate change and reducing poverty are the defining challenges of the $21^{\text {st }}$ century. Both can be tackled, and the alternative paths to sustainable growth are very attractive. We know what needs to be done, we know how to begin, and we will learn along the way. 


\section{References}

Aghion, P., Dechezleprêtre, A., Hemous, D., Martin, R. and Van Reenen, J. 2016. Carbon Taxes, Path Dependency and Directed Technical Change: Evidence from the Auto Industry, Journal of Political Economy 124(1), 1-51.

Barrett, S. 2003. Environment and Statecraft. Oxford: OUP.

Bhattacharya, A, Oppenheim, J., and Stern, N. 2015. Driving sustainable development through better infrastructure: Key elements of a transformation program. Global Working Paper no 80, Brookings Institute.

Boulding, K.E. 1966. "The economics of the coming spaceship earth" In H. Jarret.,ed., Environmental Quality Issues in a Growing Economy. Baltimore: Resources for the Future/ Johns Hopkins University Press

Bowen, A. and Kuralbayeva, K. 2015. Looking for green jobs. The impact of green growth on employment. Policy Brief, Grantham Research Institute on Climate Change and the Environment, London School of Economics and Political Science.

Braithwaite, J. and Drahos, P. 2001. Global Business Regulation. Cambridge: Cambridge University Press.

Brundtland, G., Khalid, M., Agnelli, S., Al-Athel, S., Chidzero, B., Fadika, L., Hauff, V., Lang, I., Shijun, M., de Botero, M.M. and Singh, M. 1987. Our Common Future. Oxford: Oxford University Press.

Burke, M., Hsiang, S. and Miguel, E. 2015. Global non-linear effect of temperature on economic production, Nature, doi:10.1038/nature 15725

Cline, W. 1992. The Economics of Global Warming, Washington DC: The Peterson Institute Press.

Coady,D., Parry, I., Sears, L. and Shang, B. 2015. How Large are Global Energy Subsidies? IMF Working Paper, 15/105.

Coase, R. 1960. The problem of social cost, Journal of Law and Economics, 3, 1-44.

Dechezleprêtre, A., Martin, R., and Bassi, S., 2016. Climate change policy, innovation and growth. Policy Brief, Grantham Research Institute on Climate Change and the Environment, London School of Economics and Political Science

Dechezleprêtre, A., Martin, R., and Mohnen, M., 2014. Knowledge spillovers from low-carbon technologies: A patent citation analysis. Working Paper 135, Grantham Research Institute on Climate Change and the Environment, London School of Economics. 
Dechezleprêtre, A. and Sato, M. 2014. The impacts of environmental regulations on competitiveness. Policy Brief, Grantham Research Institute on Climate Change and the Environment, London School of Economics and Political Science.

Dercon, S. 2012. Is Green Growth Good for the Poor? World Bank Policy Research Working Paper No. 6231

Drèze, J. and Stern, N. 1987. "The theory of cost-benefit analysis", in: A.J. Auerbach and M. Feldstein, eds, Handbook of Public Economics Vol. II. Amsterdam: North Holland.

Drèze, J. and Stern, N. 1990. Policy reform, shadow prices, and market prices, Journal of Public Economics, 42 (1), 1-45.

Drijfhout,S., Bathiany,S., Beaulie, C., Brovkin,V., Calussen, M,. Huntingford, C., Scheffer, M., Sgubin, G. and Swingedouw, D. 2015. Catalogue of abrupt shifts in Intergovernmental Panel on Climate Change climate models, Proceedings of the National Academy of Sciences, E5777 E5786

Edmonds, J. and Reilly, J. 1983. A long-term global energy-economic model of carbon dioxide release from fossil fuel use. Energy Economics, 5(2),74-88.

Fankhauser, S. 2013. “A Practitioner's Guide to a Low-Carbon Economy: Lessons from the UK", Climate Policy, 13(3): 345-362.

Fankhauser, S. 1995. Valuing Climate Change. The Economics of the Greenhouse. London: Earthscan.

Fankhauser, S. and McDermott T (eds). 2016. The economics of climate resilient development. Cheltenham: Edward Elgar.

Fankhauser, S. and McDermott, T.K.J. 2014. Understanding the adaptation deficit: why are poor countries more vulnerable to climate events than rich countries?, Global Environmental Change, 27, 9-18.

Freeman, J. and Kolstad C. 2007. Moving to Markets in Environmental Regulation: Lessons from Twenty Years of Experience. Oxford: Oxford University Press.

Hanley, N. and Barbier, E. 2009. Pricing Nature: Cost-Benefit Analysis and Environmental Policy-Making. Cheltenham: Edward Elgar.

Hanson, S., Nicholls, R., Ranger, N., Hallegatte,S., Corfee-Morlot,R., Herweijer,C. and Chateau, J. 2011. A global ranking of port cities with high exposure to climate extremes, Climatic Change, 104(1), 89-111.

Hartwick, J.M. 1977. Intergenerational equity and the investing of rents from exhaustible resources, American Economic Review, 67(5), 972-974. 
Heal, G. and Park, J. 2013. Feeling the heat: temperature, physiology \& the wealth of nations, NBER Working Paper No. 19725, National Bureau of Economic Research, Cambridge, MA.

Hedlund-Nyström, T., Jonung, L., Löfgren, K.G and Sandelin, B. 2006. Knut Wicksell on forestry: a note, in: L. Jonung., ed., Swedish economic thought: explorations and advances. New York: Routledge.

Hotelling, H. 1931. The economics of exhaustible resources, Journal of Political Economy, 39(2), 137-175.

Hsiang, S.M. and Burke, M., 2014. Climate, conflict, and social stability: what does the evidence say?. Climatic Change, 123(1), pp.39-55.

IPCC. 2007. Climate Change 2007: Synthesis Report. Contribution of Working Groups I, II and III to the Fourth Assessment Report of the Intergovernmental Panel on Climate Change. Geneva, IPCC.

IPCC. 2013. Climate Change 2013:The Physical Science Basis. Contribution of Working Group I to the Fifth Assessment Report of the Intergovernmental Panel on Climate Change. Cambridge: Cambridge University Press.

IPCC. 2014. Climate Change 2014: Impacts, Adaptation, and Vulnerability. Part A: Global and Sectoral Aspects. Contribution of Working Group II to the Fifth Assessment Report of the Intergovernmental Panel on Climate Change. Cambridge : Cambridge University Press.

Jackson, T. 2011. Prosperity without growth: Economics for a finite planet. London: Routledge.

Kelley, C., Mohtadi, S., Cane, M., Seager, R. and Kushnir, Y. 2015. Climate change in the Fertile Crescent and implications of the recent Syrian drought, Proceedings of the Natural Academy of Sciences. doi:10.1073/pnas.1421533112.

Keohane, R.O. and Victor, D.G. Cooperation and Discord in Global Climate Policy, Nature Climate Change, forthcoming.

Klein, N. 2015. This changes everything: Capitalism vs. the climate. New York: Simon and Schuster.

Little, I.M.D and Mirrlees, J.A. 1974. Project appraisal and planning for developing countries. New York: Basic Books.

Manne, A.S. and Richels, R.G. 1992. Buying greenhouse insurance: the economic costs of carbon dioxide emission limits. Cambridge: MIT Press.

Meade, J. 1955. Trade and Welfare. Oxford: Oxford University Press.

Meadows, D.H., Meadows, D.L., Randers, J. and Behrens, W.W. 1972. The limits to growth. New York: Universe Books. 
Met Office. 2016. Global temperatures set to reach $1^{\circ} \mathrm{C}$ marker for first time. http://www.metoffice.gov.uk/news/release/archive/2015/one-degree

Montesquieu, C. 1748. The spirit of laws. Translated by T. Nugent, New York: Cosimo Classics (2011).

New Climate Economy. 2014. Better growth, better climate, Report by the Global Commission on the Economy and Climate, London. http://2014.newclimateeconomy.report/.

National Oceanic and Atmospheric Administration (NOAA). 2016. Record annual increase of carbon dioxide observed at Mauna Loa for 2015. http://www.noaa.gov/record-annual-increasecarbon-dioxide-observed-mauna-loa-2015

Nordhaus, W. 1991a. A Sketch of the Economics of the Greenhouse Effect. American Economic Review, 81(2), 46-150.

Nordhaus, W. 1991b. To slow or not to slow: the economics of the greenhouse effect. The Economic Journal, 101(407), 920-937.

Nordhaus, W. 1982. How fast should we graze the global commons? American Economic Review, 72(2), 242-246.

OECD. 2015. OECD Companion to the Inventory of Support Measures for Fossil Fuels. Paris: OECD Publishing

Pearce, D. 2002. An intellectual history of environmental economics. Annual Review of Energy and the Environment, 27(1), 57-81.

Pearce, D. and Warford, J. 1993. World without end: Economics, environment and sustainable development. Oxford: Oxford University Press.

Pfeiffer, A., Millar, R., Hepburn, C. and Beinhocker, E. 2016. The ' $2{ }^{\circ} \mathrm{C}$ capital stock' for electricity generation: Committed cumulative carbon emissions from the electricity generation sector and the transition to a green economy, Applied Energy, in press. dx.doi.org/10.1016 /j.apenergy.2016.02.093.

Pigou, A.C. 1920. The economics of welfare. London: Macmillan.

Rhode, R.A. and Muller, R.A. 2015. Air Pollution in China: Mapping of Concentrations and Sources. PLoS One, 10.

Rockström, J., Steffen, W., Noone, K., Persson, Å., Chapin, F.S., Lambin, E.F., Lenton, T.M., Scheffer, M., Folke, C., Schellnhuber, H.J. and Nykvist, B. 2009. A safe operating space for humanity. Nature, 461(7263), 472-475. 
Sandmo, A., 2015. The early history of environmental economics, Review of Environmental Economics and Policy: 9(1): 43-63.

Schelling, T. 1992. Some economics of global warming, American Economic Review, 82(1), 114.

Schelling, T. 1997. The cost of combating global warming: facing the tradeoffs, Foreign Affairs, 76(6), 8-14.

Schlenker, W., Hanemann, W.M, and. Fisher, A.C. 2005. Will US agriculture really benefit from global warming? Accounting for irrigation in the hedonic approach, American Economic Review 95(1), 395-406.

Schlenker, W. and Lobell, D.B. 2010. Robust negative impacts of climate change on African Agriculture, Environmental Research Letters, 5:014010.

Solow, R. 1974. "Intergenerational Equity and Exhaustible Resources", Review of Economic Studies, 41, 29-45.

Stern, N. 2016. Economics: Current climate models are grossly misleading. Nature, 530(7591), 407-409.

Stern, N. 2015. Why are We Waiting? The Logic, Urgency and Promise of Tackling Climate Change. Cambridge, MA: MIT Press

Stern, N. 2007. The Economics of Climate Change. The Stern Review. Cambridge: Cambridge University Press.

Sterner, T. 2003. Policy instruments for environmental and natural resource management. Washington DC: Resources for the Future Press.

TEEB. 2010. The Economics of Ecosystems and Biodiversity. London: Earthscan.

Tol, R. and Fankhauser, S. 1998. On the representation of impact in integrated assessment models of climate change, Environmental Modelling \& Assessment, 3(1-2), 63-74.

UNEP, 2015. The Emissions Gap Report 2015. United Nations Environment Programme (UNEP), Nairobi.

Weitzman, M. 2012. GHG targets as insurance against catastrophic climate damages, Journal of Public Economic Theory, 14 (2), 221244

World Bank. 2016. Shock Waves: Managing the Impacts of Climate Change on Poverty, Climate Change and Development Series. Washington, DC.

World Bank. 2012. Turn Down the Heat: Why a $4^{\circ} \mathrm{C}$ Warmer World Must be Avoided. Washington DC. 
World Bank. 2011. The Changing Wealth of Nations. Washington DC.

World Bank. 2010. Development and Climate Change. Washington DC.

World Resources Institute. 2014. CAIT Climate Database. http://cait.wri.org/ 